\title{
DEVELOPMENT OF COMPOSITION AND INVESTIGATION OF THE NUTRIENT COMPOSITION OF THE MUFFIN"SNOWBALL"
}

\author{
Nadya Dzyuba \\ Department of restaurant and health food technology \\ Odessa National Academy of Food Technologies \\ 112 Kanatna str., Odessa, Ukraine, 65039 \\ dzyubanadya282@gmail.com \\ Liubov Telezhenko \\ Department of restaurant and health food technology \\ Odessa National Academy of Food Technologies \\ 112 Kanatna str., Odessa, Ukraine, 65039 \\ telegenko@ukr.net \\ Maryana Kashkano \\ Department of restaurant and health food technology \\ Odessa National Academy of Food Technologies \\ 112 Kanatna str., Odessa, Ukraine, 65039 \\ marykash@ukr.net \\ Maria Oliynik \\ Department of restaurant and health food technology \\ Odessa National Academy of Food Technologies \\ 112 Kanatna str., Odessa, Ukraine, 65039 \\ moleynik4@gmail.com
}

\section{Abstract}

Actualization of fast food products resulted in consumption of products with an unbalanced chemical composition that may be deficit by proteins and food fibers by a modern human. Such products negatively influence the human organism that is why it is urgent to develop compositions of products with high biological indices.

The aim of the scientific work was to develop the composition of a cheese muffin and to determine its biological value that allows to get a high protein product with a balanced chemical composition.

Using a table processor MS Excel 2010, there was developed the composition of a cheese muffin «Snowball». Its composition contains of (mass. $\%$, g): sour-milk cheese -60 , sesame seeds -5 , sugar -5 , cream butter -10 , walnuts -8 , salt -1 , raisins -7 , collagen hydrolysate (collagen preparation) - 10, wheat flour - 40. A muffin is a source of necessary macro- and micronutrients. Its consumption completely satisfies the human need in vitamins A and B6 and by $94 \%$ covers the need in phosphorus. At the expanse of introducing collagen hydrolysate in the muffin composition and change of a flour share by sour-milk cheese, there increases the protein content in the ready product (45,3\%). Consumption of 1 muffin satisfies the human organism with amino acids totally almost by $29,8 \%$.

The estimation of microbiological and organoleptic parameters at storage gives a possibility to state that a cheese muffin «Snowball» will be competitive at the consumption market. The storage term is 72 at temperature $(18 \pm 2){ }^{\circ} \mathrm{C}$, humidity no more $75 \%$ in cardboard boxes.

Keywords: cheese product, muffin, protein, collagen hydrolysate.

\section{Introduction}

Intensification of the food crisis in XXI century actualized the problem of a necessity to work on the strategic development of EU countries for supplying all population layers with healthy products. That is why a conception of supplying with healthy food, closely correlating with the material prosperity of the population logically needs studying key components at regional levels. 
The question of scientific substantiation of technological regimes, development of recipe compositions and provision of functional properties of products under conditions of using natural raw materials, safe for the organism, have a peculiar value for scientific studies. The essential attention is paid at that to the solution of a problem of structural, rheological and organoleptic properties of dessert products, and also competitiveness and economic effectiveness of introduction of developed technologies in enterprises of restaurant economy.

Taking into account the quality of the consumption basket of a modern Ukrainian, it is urgent to elaborate and to project recipe compositions of new products with the increased protein content.

\section{Review of the problem state}

The analysis of the nutrient composition of flour confectionary products (FCP) testifies to its unbalance, connected with the high content of lipids and carbohydrates and relatively low one of proteins, food fibers, vitamins, mineral elements and other biologically active substances [1]. The deficit of macro- and micronutrients results in the inability of the organism to resist the negative influence of the environment $[2,3]$.

Modern science about healthy food provides using different biologically active substances, necessary for supporting normal human life activity [4]. A source of biologically active substances may be non-traditional natural enrichment agents $[5,6]$. In this content the essential attention must be paid to products with using local raw material resources and medical-technical raw materials.

For improving the amino acid composition of flour confectionary products, there is offered to add rye peeled flour [4]. German scientists elaborated the special sort of wheat flour with K index for waffle leaves that have specific physical-chemical and rheological properties [5]. Malaysian scientists conducts works for developing products including flour of banana peel, rich of pectins and dietetic cellulose [6]. French company Roquette developed flour of alga, due to which it is possible to decrease the content of fat in food products [7].

The most cheap protein raw material with the high biological value and functional properties is proteins of oil culture seeds. It is proved, that introduction of rape seed oilcake in amount $8 \%$ gives dough a plastic consistence and also allows to enrich products with proteins and food fibers that raise not only biological, but also food value [8]. But introduction of oil cultures to recipe compositions not only enrich a product with proteins, but also fatty acids, able to oxidize at interacting with oxygen, giving a rancid taste to a ready product. This work doesn't investigate a change of a fat component of oil cultures and its influence on sensor parameters of a ready product.

There is offered to use sesame and pumpkin oilcakes [9]. Sesame oilcake essentially increases wheat flour by the content of irreplaceable amino acids: valine, lysine, threonine, phenylalanine and tyrosine, and pumpkin - by the content of phenylalanine and tyrosine, and also lysine. Pumpkin oilcake contains a great amount of polyunsaturated $\alpha$-linolenic acid [9].

In USA it is patented the method of producing FCP using fructooligosaccharides that decrease the content of cholesterol and lipids in blood and are present in many vegetables, especially in tubers of artichokes, onion, asparagus, garlic and celery roots [10]. The use of vegetable raw materials at producing FCP enriches the nutrient composition of products and increases the content of prebiotic components.

In Great Britain it is offered to replace saccharose by polyols (sugar alcohol), which energetic value is almost twice lower than sugar [11]. The use of poyols in products manufacturing provides the complete replacement of sugar, so widening of the assortment of products with a low glycemic index and high probiotic properties.

In Northern America maple syrup, which composition contains glucose, potassium, calcium and iron, is used as a natural sugar-substitute [12]. The content of glucose in maple syrup can reach $50-60 \%$ that is why such product must be used carefully in child, gerodietetic and diabetic nutrition that narrows possibilities of its use.

The use of fatless kefir as a liquid component of waffle products favors the improvement of their taste characteristics, and also increases the content of easily-assimilated proteins and calcium [13]. But the content of calcium and phosphorus for getting their optimal ratio wasn't studied. 
The use of whole seeds of wheat and grain cultures, siftings, extruded grain components, sunflower, sesame, flax seeds, nuts and so on increase a share of food fibers to $9 \mathrm{~g}[14,15]$.

There was studied the effect of the quality change of muffins at replacing wheat flour to $40 \mathrm{~g} / 100 \mathrm{~g}$ by nuts [16]. The change of $30 \mathrm{~g} / 100 \mathrm{~g}$ of wheat flour using an extruder essentially increases the height of the product. According to sensor parameters, muffins demonstrated high result 7,9 by the 9-point scale. The product quality was determined only by sensor and rheological parameters of the ready product, without taking into account the nutrient composition and ratio between main macro- and micro nutrients.

There was conducted the study for determining physical-chemical and sensor properties of the functional fatless cheese muffin [17]. The analysis of its chemical composition demonstrated that the protein content varied from $12,15 \%$ to $14,85 \%$, that in average exceeded its content in cream cheese. Introduction of sour-milk cheese in the muffin recipe essentially improved rheological and sensor parameters of the ready product. The study of its chemical composition was conducted by the content of macronutrients, without taking into account qualitative indices of micronutrients and balance among nutrients, satisfaction of human needs.

There was studied the common use of packing with the modified atmosphere and dry ovine whey for storage terms of the cheese cake [18]. Such approach to storage allowed to prolong storage terms of the ready product from 21 days to 45 days without changing sensor parameters. But the microbial mass and different temperature regimes of storage were not studied.

There was elaborated the functional cheese cake for diabetics, in which high-energy components were replaced by low-energy ones: saccharose by fructose, cream butter by olive oil, fat milk by skimmed one, chicken eggs by karish cheese [19]. The study of the influence of new dessert consumption on the glucose level in blood demonstrated that its mean level in 120 minutes reached $247,28 \pm 42,92 \mathrm{mg} / \mathrm{dl}$, that is by $30 \%$ lower at consuming a traditional cheese cake. The study analyzes the qualitative and quantitative composition of carbohydrates in the ready product and their influence on insulin-depending tissues in the human organism.

Thus, it is urgent to develop the cheese muffin with vegetable raw materials with the increased content of protein and balanced content of vitally important nutrients.

The aim of the work was to develop the composition of the cheese muffin and to determine its biological value that allows to get a high-protein product with the balanced chemical composition.

\section{Materials and Methods}

The studies were conducted on the base of scientific modern laboratories:

- Department of restaurant and health food technology Odessa National Academy of Food Technologies (Odessa city, Ukraine);

- Chemistry, expertise and safety of food products of Odessa National Academy of Food Technologies (Odessa city, Ukraine);

- Biochemistry, microbiology and physiology of nutrition of Odessa National Academy of Food Technologies (Odessa city, Ukraine).

The following equipment was used for conducting the studies:

- For preparing the muffin, there was used a blander (PHILIPS HR-1633 / 80, China), refrigerator chamber (RC-0,4 MC, Mariy El republic, Russia), electric stove (ES-4ш, Russia), washer and table electric scales (Rotex RSK 10-P, China);

- For analyzing the amino acid composition - amino acid analyzer Hitachi L-8900 (Japan).

The following raw materials were used for conducting the study: sour-milk cheese (SSU 4554:2006), sesame seeds (SSU 2240-93), sugar (SSU 4623-2006), cream butter (SSU 4399:2005), walnuts (SSU EEC UNO DDF-02:2007), salt (SSU 3583:2015), raisins (SSU 2438-94), collagen hydroysate (patent of Ukraine No. 79357), wheat flour (SSU 46.004-99).

Microbiological parameters were determined according to normative documents: bacteria of colon bacillus, coliform (SSU IDF 73A), pathogenic microorganisms, including Salmonella (SSU IDF 93A), amount of mould fungi (SS 10444.12), yeast (SS 10444.12), Staphylococcus aureus (SS 30347). 


\section{Development of the composition of cheese muffin «Snowball»}

The main stage of the recipe development was determination of quality parameters of the ready muffin. Analyzing technical characteristics of the raw materials and data of consumers' questionnaire, there was determined the priority of quality parameters of the ready muffin. 20 men and 25 women, 20-45 years old took part in the questionnaire.

At developing the recipe, the essential attention was paid to the chemical composition of the initial raw materials, its influence on biological process in the human organism.

The main criteria at choosing raw materials for the cheese muffin «Snowball» were a high biological value and a possibility to combine components for getting a product with high consumption indices. For modeling the muffin recipe, there was used the linear programming using Excel Solver inset of the table processor MS Excel 2010. The target function corresponds to the maximal protein content. The content of collagen preparation was given within $5 . .10 \%$.

For solving the problem, it is necessary to use a correspondent information data matrix. It represents the content of main nutrients of the raw materials, planned to be included in the product composition.

$$
\mathrm{Z}(\mathrm{x})=\max
$$

where $Z(x)$-target function, representing the protein content in the recipe mixture, $g$.

Limitations included:

- the recipe content of components;

- the amino acid composition of the ready product (according to $\mathrm{FAO} / \mathrm{WHO}$ ):

1) $a_{1} x_{1}+a_{1} x_{2}+a_{1} x_{3}+a_{1} x_{4}+a_{1} x_{5} \geq 0,2$,

where $\mathrm{a}_{1}-$ methionine content in component $\mathrm{x}_{\mathrm{i}}, \mathrm{g}$;

2) $\mathrm{a}_{2} \mathrm{x}_{1}+\mathrm{a}_{2} \mathrm{x}_{2}+\mathrm{a}_{2} \mathrm{x}_{3}+\mathrm{a}_{2} \mathrm{x}_{4}+\mathrm{a}_{2} \mathrm{x}_{5} \geq 0,3$,

where $a_{2}-$ lysine content in $x_{i}, g$;

3) $a_{3} x_{1}+a_{3} x_{2}+a_{3} x_{3}+a_{3} x_{4}+a_{3} x_{5} \geq 0,1$,

where $\mathrm{a}_{3}$ - tryptophan content in component $\mathrm{x}_{\mathrm{i}}, \mathrm{g}$;

The design of the calculation in MS Excel is presented on Fig. 1.

\begin{tabular}{|c|c|c|c|c|c|c|c|c|}
\hline \multicolumn{9}{|c|}{ 욜 сноубол fyuk.xlsx * $x$} \\
\hline 4 & A & B & C & D & E & $\mathrm{F}$ & G & $\mathrm{H}$ \\
\hline 1 & & $\begin{array}{l}\text { component } \\
\text { content, g }\end{array}$ & $\begin{array}{l}\text { protein } \\
\text { content } \\
\mathrm{g} / 100 \mathrm{~g}\end{array}$ & $\begin{array}{l}\text { protein content } \\
\text { in mixture, } \mathrm{g}\end{array}$ & $\begin{array}{l}\text { carbohydra } \\
\text { te content } \\
\mathrm{g} / 100 \mathrm{~g}\end{array}$ & $\begin{array}{l}\text { carbohydrate } \\
\text { content, g }\end{array}$ & $\begin{array}{l}\mathrm{Ca} \\
\text { content } \\
\mathrm{mg} / 100\end{array}$ & Ca content, mg \\
\hline 2 & fatless sour-milk cheese & 60 & 22 & $=\mathrm{B} 2 * \mathrm{C} 2 / 100$ & 40 & $=\mathrm{E} 2 * \mathrm{~B} 2 / 100$ & 120 & $=\mathrm{B} 2 * \mathrm{G} 2 / 100$ \\
\hline 3 & sesame & 5 & 19,4 & $=\mathrm{B} 3 * \mathrm{C} 3 / 100$ & 0 & $=\mathrm{E} 3 * \mathrm{~B} 3 / 100$ & 1474 & $=\mathrm{B} 3{ }^{*} \mathrm{G} 3 / 100$ \\
\hline 4 & sugar-sand & 5 & 0 & $=\mathrm{B} 4 * \mathrm{C} 4 / 100$ & 0 & $=\mathrm{E} 4 * \mathrm{~B} 4 / 100$ & 0 & $=\mathrm{B} 4 * \mathrm{G} 4 / 100$ \\
\hline 5 & cream butter & 10 & 0,8 & $=\mathrm{B} 5 * \mathrm{C} 5 / 100$ & 1,3 & $=\mathrm{E} 5 * \mathrm{~B} 5 / 100$ & 24 & $=\mathrm{B} 5{ }^{*} \mathrm{G} 5 / 100$ \\
\hline 6 & walnuts & 8 & 16,2 & $=\mathrm{B} 6^{*} \mathrm{C} 6 / 100$ & 77 & $=\mathrm{E} 6 * \mathrm{~B} 6 / 100$ & 89 & $=\mathrm{B} 6^{*} \mathrm{G} 6 / 100$ \\
\hline 7 & salt & 1 & 0,1 & $=\mathrm{B} 7 * \mathrm{C} 7 / 100$ & 0,1 & $=\mathrm{E} 7 * \mathrm{~B} 7 / 100$ & 0 & $=\mathrm{B} 7 * \mathrm{G} 7 / 100$ \\
\hline 8 & raisins & 7 & 1,8 & $=\mathrm{B} 8 * \mathrm{C} 8 / 100$ & 66 & $=\mathrm{E} 8 * \mathrm{~B} 8 / 100$ & 80 & $=\mathrm{B} 8 * \mathrm{G} 8 / 100$ \\
\hline 9 & collagen preparation & 10 & 70 & $=\mathrm{B} 9 * \mathrm{C} 9 / 100$ & 0 & $=\mathrm{E} 9 * \mathrm{~B} 9 / 100$ & 0 & $=\mathrm{B} 9 * \mathrm{G} 9 / 100$ \\
\hline 10 & wheat flour & 40 & 11,1 & $=\mathrm{B} 10^{*} \mathrm{C} 10 / 100$ & 67,8 & $=\mathrm{E} 10 * \mathrm{~B} 10 / 100$ & 24 & $=\mathrm{B} 10^{*} \mathrm{G} 10 / 100$ \\
\hline 11 & ready product output, $\mathrm{g}$ & $=\mathrm{SUM}(\mathrm{B} 2: \mathrm{B} 10)$ & & $=\mathrm{SUM}(\mathrm{D} 2: \mathrm{D} 10)$ & & $=\mathrm{SUM}(\mathrm{F} 2: \mathrm{F} 10)$ & & $=\mathrm{SUM}(\mathrm{H} 2: \mathrm{H} 10)$ \\
\hline 12 & & & & & & & & \\
\hline
\end{tabular}

Fig. 1. Matrix of muffin composition planning

Limitations for the muffin recipe composition are given on Fig. 2. The obtained recipe is given in Fig. 3. 


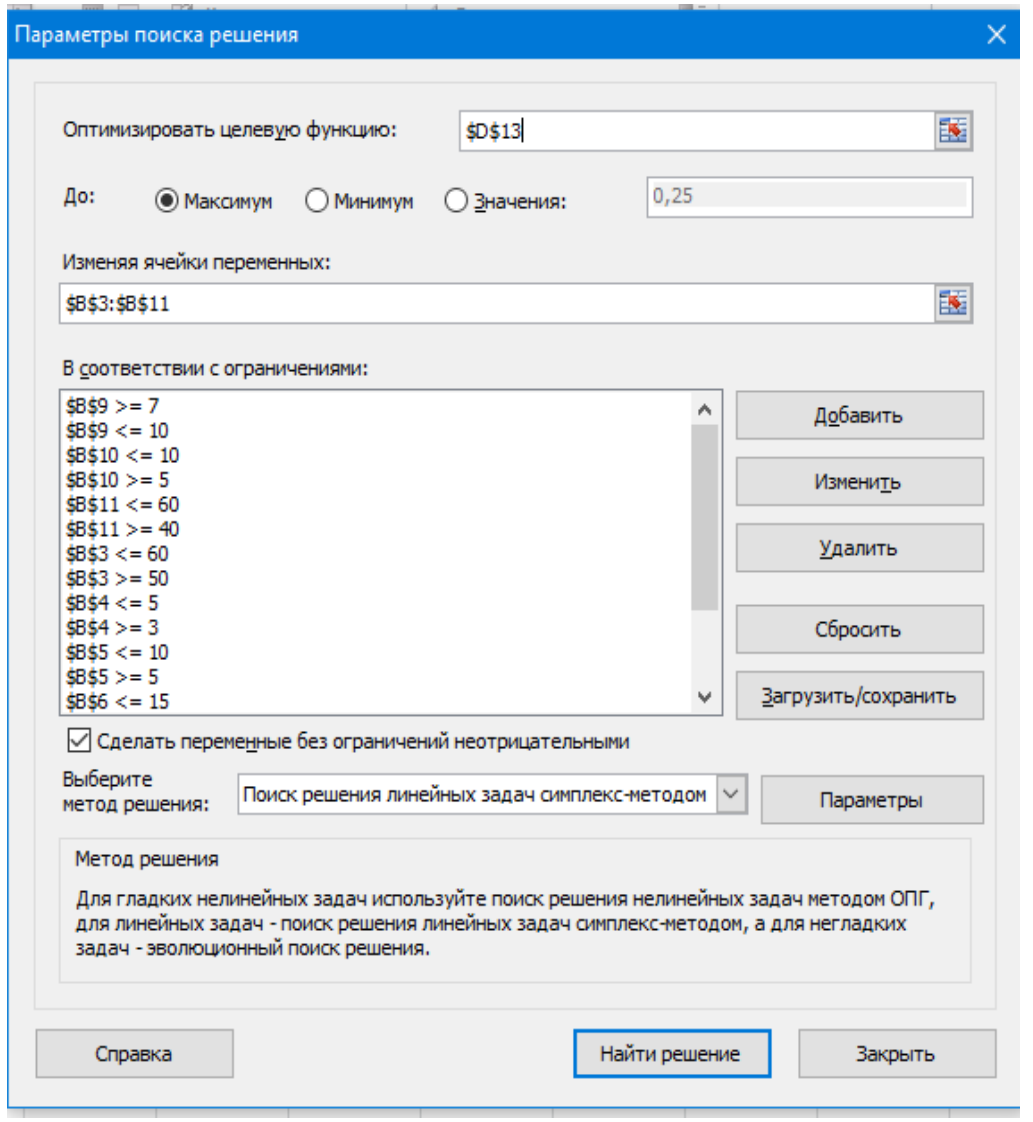

Fig. 2. Limitations for the recipe composition

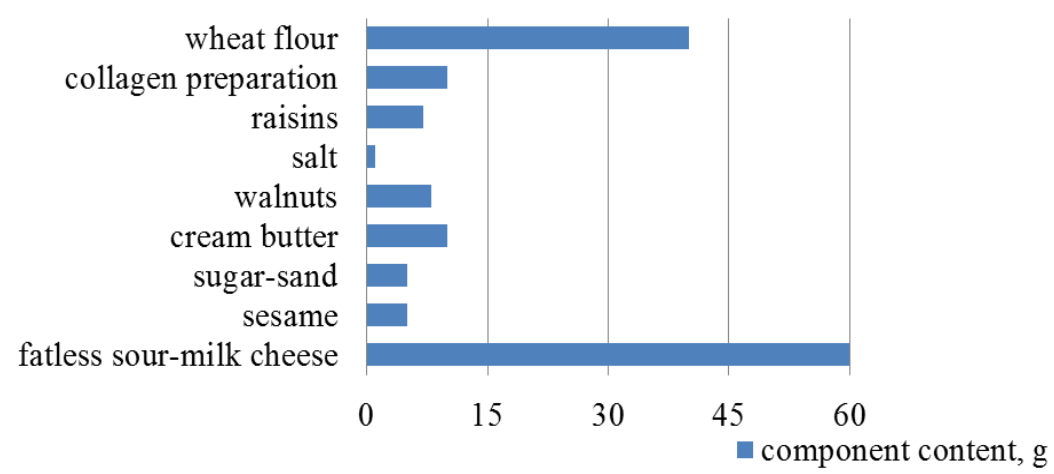

Fig. 3 «Snowball» muffin recipe

\section{Analysis of the nutrient composition of «Snowball» cheese muffin}

The study of the micronutrient composition (Table 1) demonstrated that consumption of one muffin completely satisfies human needs in vitamins $\mathrm{A}$ and $\mathrm{B}_{6}$. It must be noted, that the developed product differs by rather high content of all other main nutrients, necessary for the human organism, namely calcium, potassium, phosphorus, iron (Table 1).

The obtained results (Table 1) testify that the developed muffin is a source of vitamins, especially ones of B group, and also is rich in vitamins-antioxidants (tocopherol, nicotine and ascorbic acids).

As far as the ready muffin contains protein, the amino acid composition must be studied. The research results demonstrated that the protein component contains nineteen amino acids, including all irreplaceable ones. The biological value of the studied muffin was determined by the calculation of amino acid score, presented on Fig. 4. 
Table 1

Satisfaction degree of the human daily need in main vitamins, \% (at consuming 1 muffin)

\begin{tabular}{cccc}
\hline Vitamins & Daily need, $\mathbf{m g}$ & Muffin, $\mathbf{m g}$ & Satisfaction of daily need, \% \\
\hline A & 0,1 & 0,1328 & 132,80 \\
$\mathrm{~B}_{1}$ & 1,5 & 0,2604 & 20,49 \\
$\mathrm{~B}_{2}$ & 1,8 & 0,3688 & 190,18 \\
$\mathrm{~B}_{6}$ & 0,2 & 0,38036 & 6,55 \\
E & 15 & 0,9828 & 33,84 \\
PP & 20 & 6,768 & 2,31 \\
C & 80 & 1,85 & 11,0 \\
Calcium (Ca) & 3000 & 329,3 & 13,9
\end{tabular}

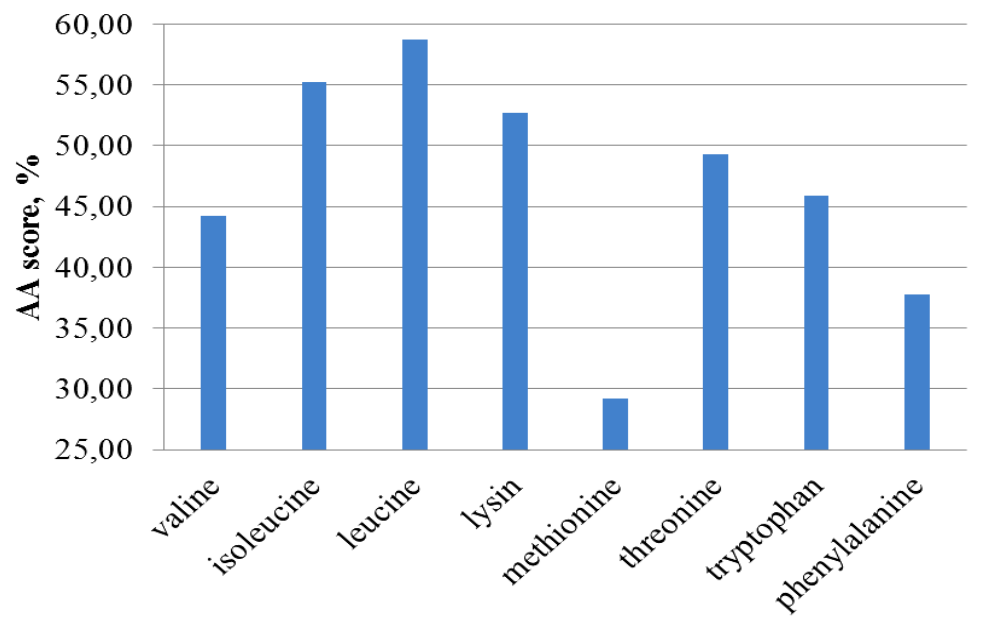

Fig. 4. Amino acid score

The obtained data demonstrate that the first limiting amino acid is methionine (AA score $=29,16 \%$ ).

The organism daily need in irreplaceable amino acids at the expanse of consuming 1 muffin is presented in Table 2. Consumption of 1 muffin provides the human organism with irreplaceable amino acids totally by $29,8 \%$.

The recipe peculiarities of the muffin were reflected on the change of its fatty acid composition. The analysis of the fatty acids composition demonstrated that saturated fatty acids (SFA) prevail in the developed muffin, their share is $48,5 \%$. The sum of monounsaturated fatty acids (MUFA) is at the second place and is $28 \%$, the content of polyunsaturated fatty acids (PUFA) is $23,5 \%$. The indices of biological effectiveness of the fatty component of «Snowball» muffin by the ratio of fatty acid fractions are presented in Table 3. 
Table 2

Satisfaction degree of the human daily need in amino acids, \% (at consuming 1 muffin)

\begin{tabular}{cccc}
\hline Amino acid & Daily need in $\mathbf{~}$ & Content, g/1 portion & Satisfaction, $\%$ \\
\hline valine & 3 & 1,1 & 37,13 \\
isoleucine & 3 & 1,0 & 33,42 \\
leucine & 5 & 1,9 & 37,26 \\
lysin & 4 & 1,3 & 32,84 \\
methionine & 3 & 0,5 & 15,42 \\
threonine & 2 & 0,9 & 44,68 \\
tryptophan & 2 & 0,2 & 10,41 \\
phenylalanine & 3 & 1,0 & 34,26 \\
Arginine & 6 & 1,5 & 25,22
\end{tabular}

Table 3

Indices of biological effectiveness of lipids

\begin{tabular}{ccc}
\hline \multirow{2}{*}{ Sample } & \multicolumn{2}{c}{ Ratio } \\
\cline { 2 - 3 } & UFA:MUFA:PUFA & PUFA: UFA \\
\hline Ideal lipid & $1: 1: 1$ & $0,2-0,4$ \\
Muffin & $2: 1: 1$ & 0,48
\end{tabular}

As it is seen on Table 3, the ratio UFA:MUFA:PUFA doesn't correspond to requirements as to the ideal lipid: UFA content is twice higher than recommended ratios, according to the daily consumption need. But taking into account that the muffin is not a main food product, daily satisfaction with UFA may be corrected by consuming nuts.

Most often the main criterion for a consumer is organoleptic parameters. The assessment of organoleptic parameters of the obtained muffin is given in Table 4. The cheese muffin was organoleptically assessed, according to requirements of the actual standard SSU 2781-98. It was assessed by the sensor method by the parameters, provided by the standard: outlook, consistence, color, taste, smell. The organoleptic assessment was realized by the gustatory commission, included the teaching staff of the department of Technology of restaurant and healthy food and representatives of the producing-teaching complex "Restaurant 112" (Odessa national academy of food technologies).

Table 4

Organoleptic parameters of muffin

\begin{tabular}{cl}
\hline Name of parameter & \multicolumn{1}{c}{ Characteristic of muffin } \\
\hline Outlook & Correct, form corresponds to the product, evenly baked, without burnt spots \\
Consistence & Soft, crumbly, free, vegetable raw materials are distributed evenly along the whole volume \\
Color & From light-yellow to yellow, raisins and nuts have a natural color \\
Smell & Milky, with tints of sour milk and nuts, pure, without side smells \\
Taste & Sweet, light-sour milky with a nut aftertaste
\end{tabular}

The developed «Snowball» muffin is a product with dry substances content $69,8 \%$, and protein content $45,3 \%$ (Fig. 5). 


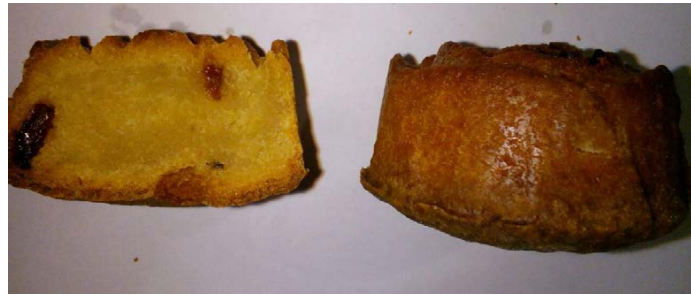

Fig. 5. Outlook of «Snowball» muffin

At storage of the muffin different physical-chemical changes that influence the ready product quality are possible.

For substantiating storage conditions and terms, muffins were stored according to requirements for cakes in cardboard boxes at temperature $(18 \pm 3)^{\circ} \mathrm{C}$, humidity no more $75 \%$. The data of physical-chemical and microbiological parameters of the muffin at storage are presented in Table 5.

Table 5

Dynamics of changes of physical-chemical and microbiological parameters of the muffin at storage in cardboard package

\begin{tabular}{|c|c|c|c|c|c|}
\hline \multirow{2}{*}{ Name of parameter } & \multirow{2}{*}{$\begin{array}{l}\text { Characteristic of parameters after } \\
\text { ending the technological cycle }\end{array}$} & \multicolumn{4}{|c|}{ Storage duration, hours } \\
\hline & & 24 & 48 & 72 & 96 \\
\hline \multicolumn{6}{|c|}{ Physical-chemical parameters } \\
\hline Acidity & 2,4 & 2,4 & 2,5 & 2,7 & 3,0 \\
\hline Humidity, \% & 8,2 & 8,1 & 8,0 & 7,4 & 7,0 \\
\hline \multicolumn{6}{|c|}{ Microbiological parameters } \\
\hline $\mathrm{BCBG}$ in $1 \mathrm{~g}$ & Not revealed & \multicolumn{4}{|c|}{ Not revealed } \\
\hline Coagulo-positive staphylococcus & Not revealed & \multicolumn{4}{|c|}{ Not revealed } \\
\hline $\begin{array}{l}\text { Pathogenic microorganisms, including } \\
\text { Salmonella }\end{array}$ & Not revealed & \multicolumn{4}{|c|}{ Not revealed } \\
\hline MAFAM, CCU in $1 \mathrm{~g}$, no more than & $3,1 \cdot 10^{2}$ & $3,5 \cdot 10^{2}$ & $4,1 \cdot 10^{2}$ & $4,4 \cdot 10^{2}$ & $5,1 \cdot 10^{2}$ \\
\hline Mould fungi in $1 \mathrm{~g}$ no more than & $3,1 \cdot 10^{1}$ & $3,4 \cdot 10^{1}$ & $3,7 \cdot 10^{1}$ & $3,9 \cdot 10^{1}$ & $4,1 \cdot 10^{1}$ \\
\hline
\end{tabular}

The dynamics of changes of the organoleptic parameters in the point system is presented on Fig. 6. Intervals of values changes of the organoleptic parameters P1 were considered as $0-5$ points: 0-1 - very bad quality, $1-2$ - bad quality; $2-3-$ middle quality; $3-4-$ good quality; $4-5-$ perfect quality.

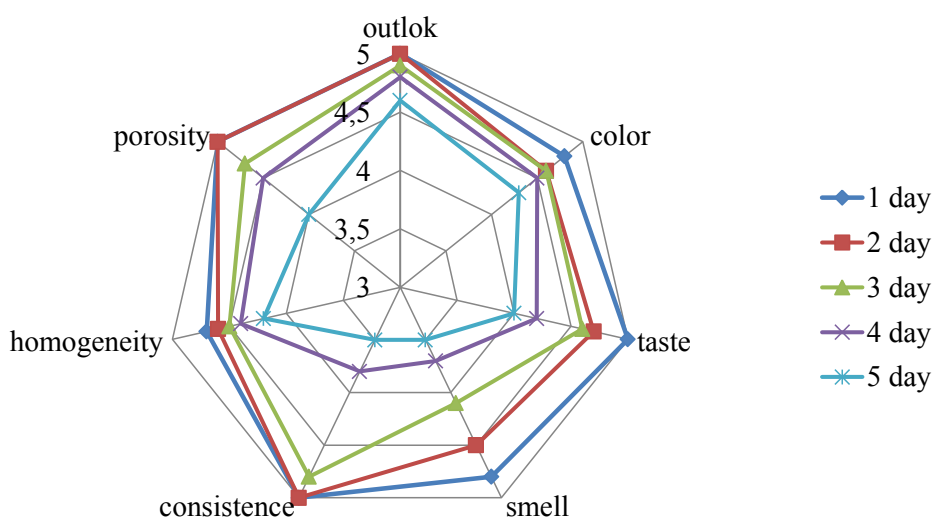

Fig. 6. Dynamics of changes of the muffin organoleptic parameters at storage 
Thus, based on the conducted studies, storage term 72 hours at temperature $(18 \pm 2){ }^{\circ} \mathrm{C}$, humidity no more $75 \%$ in cardboard boxes is recommended.

\section{Conclusions}

1. Using Excel Solver inset and table processor MS Excel 2010, there was developed the composition of the cheese muffin «Snowball», with the balanced protein-carbohydrate composition. Its composition contains the following components: sour-milk cheese, sesame seeds, sugar, cream butter, walnuts, salt, raisins, collagen preparation and wheat flour.

2. The chemical composition of the developed muffin was studied, the high content of micronutrients in it was proved. The analysis of the quality composition of amino acids demonstrated the presence of all irreplaceable amino acids with rather high amino acid score. The analysis of the fatty acid composition of the muffin demonstrated the increased content of unsaturated fatty acids that can be regulated by introducing nuts in the recipe or in the human ration.

3. Determination of storage terms and conditions demonstrated that the quality parameters in the muffin don't undergo essential changes. The recommended storage conditions are the following: $(18 \pm 3){ }^{\circ} \mathrm{C}$, humidity no more $75 \%$ during 72 hours.

4. The developed compositions of the cheese muffin can be realized in production conditions of restaurant economy enterprises. For introducing it in real conditions, it is necessary to conduct economic calculations, determining its commercial price, including material expenditures for advertising. In further studies it is planned to conduct the analysis of production technologies of the developed muffin, determining critical production points.

\section{References}

[1] Lozova, T. M., Syrokhman, I. V. (2017). Naukove obgruntuvannia polipshennia spozhyvnykh vlastyvostei boroshnianykh kondyterskykh vyrobiv z vykorystanniam pryrodnoi netradytsiynoi syrovyny. Lviv, 328.

[2] Deinychenko, V. H., Yudicheva, O. P. Biofortyfikovani kharchovi produkty novoho pokolinnia: znachennia dlia ratsionalnoho i bezpechnoho kharchuvannia. Available at: http://dspace.puet.edu.ua/handle/123456789/1935

[3] Turchaninov, D. V., Vil'ms, E. A., Boyarskaya, L. A., Turchaninova, M. S. (2015). The impact diet and lifestyle on public health: current approaches to assessment and strategies for prevention. Pyshchevaia pomishlennost, $1,8-11$.

[4] Magomedov, G. O., Bogdanov, V. V., Evseev, N. V., Kvashnina, A. E., Bugaeva, E. V., Taratuhin, A. S. (2013). Muchnye konditerskie izdeliya povyshennoy pishchevoy cennosti. Konditerskoe i hlebopekarnoe proizvodstvo, 1-2, 42-43.

[5] Hanneforth, U. (1998). Nicht jedes Mehl eignet sich zum Backen von Waffeln. ZSM: Zuskerund Sussawaren Wirt, 51 (3), 110-114.

[6] Tarasenko, N. A. (2013). Vafli ponizhennoy kaloriynosti s ispol'zovaniem pishhevykh volokon y stevyozyda. Produkti i inghredyenty, 7, 22-24.

[7] Plutenko, Ja., Jurova, S. (2013). Interesnoe o muke iz vodorostey, ghrechky y bananovoy kozhury. Khlibopekars'ka i kondyters'ka promyslovist' Ukrainy, 5, 18-19.

[8] Manzhesov, V. Y., Trukhman, S. V., Kurchaeva, E. E. (2014). Produkti pererabotky semyan rapsa v proyzvodstve muchnykh kondyterskykh izdeliy. Kondyterskoe proyzvodstvo, 6, 9-10.

[9] Bochkarev, M. S., Bochkareva, K. A., Eghorova, E. Ju. (2013). Razrabotka recepturi pyshhevogho koncentrata. Kondyterskoe y khlebopekarskoe proyzvodstvo, 7-8, 49-50.

[10] Johnson, S. D., De Cock, P. W. H. A., Nana, R., Schwetlik, G. R., Zoerb, H. (2002). Pat. No. 426/ 548SShA, MPK A23L001/236 (2002.11). Zmenshennia enerhetychnoi tsinnosti kondyterskykh vyrobiv. No. US7867544; declareted: 04.11.2002; published: 06.05.2002, Bul. No. 11.

[11] Zumbé, A., Lee, A., Storey, D. (2001). Polyols in confectionery: the route to sugar-free, reduced sugar and reduced calorie confectionery. British Journal of Nutrition, 85 (S1), S31. doi: https://doi.org/10.1079/ bjn 2000260

[12] Maple Products European Market Analysis // Agriculture and Agri-Food Canada. Available at: http://www.agr.gc.ca/eng/industry-markets-and-rade/statistics-and-market-information/by-region/europe/ maple-products-european-marketanalysis/?id=1424352808569 
[13] Fedorova, D. V. (2016). New salty waffle products "Fish Krekis" with fish \& plant semifinished products. TRAEKTORIÂ NAUKI, 4 (9). 3.6-3.17. Available at: http://pathofscience.org/index.php/ps/article/ view/113

[14] Knorr, D. (1977). Potato protein as partial replacement of wheat flour in bread. Journal of Food Science, 42 (6), 1425-1427. doi: https://doi.org/10.1111/j.1365-2621.1977.tb08390.x

[15] Sidhu, J. S., Kabir, Y., Huffman, F. G. (2007). Functional Foods from Cereal Grains. International Journal of Food Properties, 10 (2), 231-244. doi: https://doi.org/10.1080/10942910601045289

[16] Marchetti, L., Califano, A. N., Andrés, S. C. (2018). Partial replacement of wheat flour by pecan nut expeller meal on bakery products. Effect on muffins quality. LWT, 95, 85-91. doi: https://doi.org/10.1016/ j.lwt.2018.04.050

[17] Yasin, N. M. N., Shalaby, S. M. (2013). Physiochemical and sensory properties of functional low fat cheesecake manufactured using cottage cheese. Annals of Agricultural Sciences, 58 (1), 61-67. doi: https://doi.org/10.1016/j.aoas.2013.01.009

[18] Secchi, N., Fadda, C., Sanna, M., Conte, P., Del Caro, A., Catzeddu, P., Piga, A. (2017). Effectiveness of modified atmosphere packaging and ovine whey powder in extending the shelf life of whey cheesecakes. LWT, 75, 373-378. doi: https://doi.org/10.1016/j.lwt.2016.09.018

[19] Abdel-Salam, A. M., Ahmed, S. M. (2007). Preparation and evaluation of formulated functional cheesecake for diabetics. Journal of Food, Agriculture \& Environment, 5 (3-4), 8-11.

\title{
DEVELOPMENT OF NEW CRISPY BREADS WITH THE INCLUSION OF VEGETABLE ADDITIVES AND EVALUATION OF THEIR QUALITY
}

\author{
Maryna Mardar \\ Vice-Rector for Scientific and Pedagogical Work and International Relation \\ Odessa National Academy of Food Technologies \\ 112 Kanatna str., Odessa, Ukraine, 65039 \\ marinamardar2003@gmail.com \\ Tetiana Bordun \\ Department of technology of mixed feed and biofuel \\ Odessa National Academy of Food Technologies \\ 112 Kanatna str., Odessa, Ukraine, 65039 \\ bordun.tatjana@gmail.com \\ Rafaela Znachek \\ Department of Marketing, Business and Trade \\ Odessa National Academy of Food Technologies \\ 112 Kanatna str., Odessa, Ukraine, 65039 \\ rafaehlab@yandex.ru \\ Svitlana Vikul \\ Department of Food chemistry and expertise \\ Odessa National Academy of Food Technologies \\ 112 Kanatna str., Odessa, Ukraine, 65039 \\ vizaj_vik@ukr.net
}

Abstract

Spelt-based crispy breads with the inclusion of herbal supplements (powders of milk thistle, mountain ash, wild rose and green tea extract) and the results of assessing the quality of new products by organoleptic and physico-chemical indicators are 